\title{
25 Research Square \\ Combined Effects of Inoculating Serendipita Indica on Soybean Growth and Soil Health Under Cd Stress
}

Xiaohui Wang

Heilongjiang University

Xiaoxu Fan

Heilongjiang University

Weidong Wang

Heilongjiang Bayi Agricultural University

Fuqiang Song ( 0431sfq@163.com )

Heilongjiang University https://orcid.org/0000-0001-7754-5058

\section{Research Article}

Keywords: photosynthesis, soil enzyme activity, ICP-MS, Cadmium (Cd), heavy metal, bioremediation

Posted Date: May 27th, 2021

DOI: https://doi.org/10.21203/rs.3.rs-463405/v1

License: (c) (1) This work is licensed under a Creative Commons Attribution 4.0 International License. Read Full License 


\section{Abstract}

Cadmium (Cd) pollution in the soil is a global environmental problem. Plants-microbial technology has been regarded as a potential technique for the remediation of $\mathrm{Cd}$ polluted soils. Here, we aimed to explore the combined effects of inoculating (Serendipita indica) $S$. indica on soybean growth and soil health under $\mathrm{Cd}$ stress. Therefore, a pot experiment was conducted to investigate the $S$. indica on soybean growth and the soil enzyme activities, $\mathrm{pH}$ and chemical forms of $\mathrm{Cd}$ in the soil under $\mathrm{Cd}$ 0, 10, 20, 30 $\mathrm{mg} / \mathrm{kg}$ soil teatments. Results reflected that compared to non-inoculated ones, the application of $S$. indica can still enhance the dry weight (66.57\%), shoot height $(90.35 \%)$ and promote the net photosynthesis rate (72.18\%), transpiration ratio $(80.73 \%)$, and stomatal conductance $(119.05 \%)$ photosynthesis of soybean under $\mathrm{Cd} 30 \mathrm{mg} / \mathrm{kg}$ soil. Furthermore, The pH, phosphatase (116.39\%) and catalase (4.17\%) activities in the $S$. indica treatments were increased under $\mathrm{Cd} 10 \mathrm{mg} / \mathrm{kg}$ soil. Meanwhile, inoculated $S$. indica treatments significantly shifted $\mathrm{Cd}$ from exchangeable fraction to other more stable fractions, primarily decreased Cd concentrations (23.66\%) under $\mathrm{Cd} 20 \mathrm{mg} / \mathrm{kg}$ soil. The Cd pollution assessment in soil indicated that $S$. indica could effectively reduce Cd pollution in the $\mathrm{Cd} 10 \mathrm{mg} / \mathrm{kg}$ soil treatments. This work suggests that $S$. indica may be a potential method for not only promoting plant growth, but also relieving the phytotoxicity of $\mathrm{Cd}$ and remediating $\mathrm{Cd}$ contaminated soil.

\section{Introduction}

Soil heavy metal pollution is one of the main factors restricting the safety and development of agricultural products, which has caused great ecological damage to the environment. On the one hand, the heavy metals in soil come from the waste water, waste residue and waste gas discharged in the process of industrial production, on the other hand, they come from the excessive use of pesticides and chemical fertilizers by farmers. $\mathrm{Cd}$ is one of the most dangerous elements to the environment and human health because of its dynamic migration and easy accumulation. It is also an unnecessary, undegradable and harmful element to plants and humans (Satarug et al. 2004). When the accumulation of Cd in the soil exceeds the tolerance range of plants, the physiological and respiratory processes of plants will be disordered and plant growth will be hindered (Sebastian et al. 2019).

Soybean (Glycine max (Linn.) Merr.), as the main crop in Asian countries, plays a crucial role in providing proteins because it can fix nitrogen by endosymbiotic nodule bacteria and improve soil fertility. However, Cd seriously affects the growth of soybean and potentially leads to severe impacts on public health (Xian et al. 2020; Zhi et al. 2020). Furthermore, oxalate accumulation induced by Cd contributes to the inhibition of root growth in soybean. Overexpression of wild soybean Oxalyl-CoA synthetase can reduce oxalate accumulation and increase $\mathrm{Cd}$ tolerance of hairy soybean roots (Xian et al. 2020). Therefore, we hope that $\mathrm{Cd}$ can be fixed in the soil and not easily absorbed by plants. Also, even if plants absorb $\mathrm{Cd}$, it can be enriched in the non edible parts, so that the edible parts of plants have no or low concentrations of $\mathrm{Cd}$. The technology of symbiosis between endophytic fungi and plants has the potential to solve these problems. (Li et al. 2020). 
The root endophytic fungus, $S$. indica, can colonize in the roots of plenty of plant species and promote the absorption of nutrients. Besides, the antioxidant defense system of the plant can be enhanced by the fungus, which has a vital role in resistance against biotic and abiotic stresses (Valente 2019). S. indica can regulate the hormone level of plants to resist Cd stress by mediating the signal transduction of salicylic acid, ethylene, jasmonic acid and other plant hormones. (Akum et al. 2015; Alga et al. 2011; Ruchika et al. 2018; Hilbert et al. 2013). A successful S. indica colonization can enhance the secretion of defensive secondary metabolites, such as catalase, ascorbic acid and glutathione to remove the active oxygen caused by Cd toxicity (Padash et al. 2016; Shayan et al. 2017; Shahabivand et al. 2017; Vahabi et al. 2016). Moreover, $S$. indica can accumulate $C d$ in the plant roots and restrict their movement to aerial parts (Shahabivand et al. 2017).

The symbiotic relationship between fungi and host plants can produce a synergistic effect on Cd phytoremediation. There were few reports on the physiological characteristics and soil health of soybean under $\mathrm{Cd}$ stress. Therefore, in this research, we hypothesized that $S$. indica could promote soybean growth and transform $\mathrm{Cd}$ into a form, which is not easily utilized by plants under high $\mathrm{Cd}$ stress, thus reducing the risk of $\mathrm{Cd}$ flowing into the food chain. We conducted pot experiments to determine the effects of $\mathrm{Cd}$ stress and $\mathrm{S}$. indica on soybean growth, soybean physiological characteristics, the enzyme activities and the accumulation of $\mathrm{Cd}$ in the soil. In addition, the ecological risk of soybean soil inoculated with $S$. indica was analyzed to reveal the application prospect of $S$. indica in the remediation of $\mathrm{Cd}$ contaminated farmland.

\section{Materials And Methods}

\section{Plant and fungal materials}

Heinong 48 soybean seeds purchased from seed station, Harbin, China. Seeds were surface sterilized by soaking in 70\% ethanol for $2 \mathrm{~min}$ and $4 \%$ sodium hypochlorite for $10 \mathrm{~min}$, and then washed with double distilled water for 4 times. $S$. indica, is a strain preserved and propagated in the laboratory, was cultured in Petri dishes on a Hill \& Käfer (2001) medium at $30 \pm 1^{\circ} \mathrm{C}$ in the dark for 14 days. The mycelium plugs of $S$. indica $(10 \mathrm{~mm})$ were taken from the edge of the fungus culture plates $\left(7.3 \times 10^{4}\right.$ spore / plug). The fungal plugs of non-S. indica treatments were the same as $S$. indica treatments but it was autoclaved.

\section{Soil preparation}

The soil of pot experiment was collected from farmland soil around Nangang District of Harbin City, Heilongjiang Province, PR China, is a typical black soil, and then physicochemically characterized: The soil pH was 7.8 , organic matter content was $24.3 \mathrm{~g} / \mathrm{kg}$, total nitrogen was $1.8 \mathrm{~g} / \mathrm{kg}$, available nitrogen was $50.3 \mathrm{mg} / \mathrm{kg}$, available potassium was $213.1 \mathrm{mg} / \mathrm{kg}$, available phosphorus was $9.2 \mathrm{mg} / \mathrm{kg}$, and background Cd concentration is $0.128 \mathrm{mg} / \mathrm{kg}$ soil. Air-dried soil was sieved with a $2 \mathrm{~mm}$ sieve and autoclaved sterilized 3 times at $100^{\circ} \mathrm{C}$ for $1 \mathrm{~h}$ to eliminate $\mathrm{AM}$ fungal spores and other microorganisms activities. After that, four concentrations of $\mathrm{Cd}(0,10,20$ and $30 \mathrm{mg} / \mathrm{kg}$ soil) were added to the soil in the 
form of $\mathrm{CdCl}_{2} \cdot 5 \mathrm{H}_{2} \mathrm{O}$ aqueous solution. Then the soil samples were incubated at $20^{\circ} \mathrm{C}$ for 30 days to make the $\mathrm{Cd}$ evenly distributed and stabilized in the soil solid phase.

\section{Experimental design}

The greenhouse experiment was conducted in a $2 \times 4$ factorial design with a completely random design.

Two $S$. indica treatments were - S (non-inoculation / control) and + S (S. indica); Four soil Cd concentrations were $\mathrm{Cd} 0 \mathrm{mg} / \mathrm{kg}$ soil (CK), Cd $10 \mathrm{mg} / \mathrm{kg}$ soil (LH), $\mathrm{Cd} 20 \mathrm{mg} / \mathrm{kg}$ soil (MH), and Cd 30 $\mathrm{mg} / \mathrm{kg}$ soil $(\mathrm{HH})$. Each treatment was repeated 10 times.

\section{Sampling}

Each experimental plastic pot $\left(30 \times 15 \times 15 \mathrm{~cm}^{3}\right)$ was filled with $5 \mathrm{~kg}$ four added Cd concentrations soil and five soybean seeds with one fungal plug below. Every pot was watered once every four days. The soybean plants were harvested after about 120 days of planting (June 4 th - October 4 th, 2018). The shoots and roots were rinsed with distilled water, wiped with tissue paper and weighted. Then, shoot height was determined, and finally dried at $75^{\circ} \mathrm{C}$ for $48 \mathrm{~h}$ to determine the dry weights and $\mathrm{Cd}$ concentrations. Furthermore, root subsamples were stored in $50 \%$ ethanol for root colonization assessment. The rhizosphere soil samples were collected from each basin, thoroughly mixed, passed through 10, 60 and 100 mesh nylon screens, and divided into two parts for storage: one part was air-dried for the determination of soil $\mathrm{pH}, \mathrm{Cd}$ content and chemical form, and one part was preserved at $4^{\circ} \mathrm{C}$ for the determination of soil enzyme activity.

\section{Root colonization}

The tryphan blue was used to estimated root colonization according to Phillip's (1970) method. After 60 days of co culture, 3 samples were randomly selected from each treatment. The roots were washed with distilled water, cut into $1 \mathrm{~cm}$ root pieces, and put in $10 \% \mathrm{KOH}$ solution overnight, then washed with distilled water for 3-5 times. After soaking in $1 \% \mathrm{HCl}$ for 3-5 min, $0.05 \%$ trypan blue staining was performed for 1 min, After that, the root pieces were washed in distilled water for 8-10 times. Slides were prepared and observed under the light microscope, and took photographs.

\section{Measurement of photosynthesis}

At the blooming stage of soybean, the net photosynthetic rate (Pn), stomatal conductance ( $\mathrm{Tr}$ ), intercellular $\mathrm{CO}_{2}$ concentration ( $\mathrm{Ci}$ ), and transpiration rate (Gs) of the flag leaves were measured by an ultra-light portable photosynthesis system (Cl-340, CID Inc., USA) during 9:00 11:00 am, July 20th, 2018.

\section{Soil enzyme activities}

The soil urease activity was assayed by phenol sodium colorimetric method, and the results were expressed as the number of milligrams of NH3-N released in $1 \mathrm{~g}$ of soil after incubation at $37{ }^{\circ} \mathrm{C}$ for $24 \mathrm{~h}$ (mg / g). The soil sucrase activity was measured by 3, 5 - dinitrosalicylic acid colorimetry (DNS method), and the results were expressed as the number of milligrams of glucose hydrolyzed in $1 \mathrm{~g}$ of soil after incubation at $37^{\circ} \mathrm{C}$ for $24 \mathrm{~h}(\mathrm{mg} / \mathrm{g})$. The soil phosphatase activity was assayed by sodium diphenyl 
phosphate colorimetry method, and the results were expressed as the number of milligrams of phenol released in $1 \mathrm{~g}$ of soil after incubation at $37^{\circ} \mathrm{C}$ for $24 \mathrm{~h}(\mathrm{mg} / \mathrm{g})$. The soil catalase activity was determined by UV spectrophotometry $(240 \mathrm{~nm})$, and the results were expressed as the number of milligrams of hydrogen peroxide consumed in $1 \mathrm{~g}$ of soil after incubation at $20{ }^{\circ} \mathrm{C}$ for $0.5 \mathrm{~h}(\mathrm{mg} / \mathrm{g})$ (Yang et al. 2007; Ge et al. 2017; Trasar. 1999).

\section{Cd determination}

Cd content was analyzed according to Vieira et al. (2005). The dried soil samples $(0.25 \mathrm{~g})$ were digested with $\mathrm{HNO}_{3}$ and $\mathrm{HClO}_{4}(5: 1)$ in a microwave oven. The $\mathrm{Cd}$ concentrations were estimated by an inductively coupled plasma mass spectrometry (ICP-MS, XSeries2, ThermoFisher Scientific, Waltham, MA, USA).

\section{Determination of Cd chemical forms}

According to Tessier method (1979), all the soil samples were extracted in sequence to determine the form of $\mathrm{Cd}$ in the soil. $\mathrm{Cd}$ were divided into five different forms: exchangeable form $\left(\mathrm{MgCl}_{2}, \mathrm{pH}=7\right)$; carbonate form ( $\mathrm{NaOAc}, \mathrm{pH}=5)$; reducible iron and manganese form $\left(\mathrm{NH}_{4} \mathrm{OH}+\mathrm{HCl}\right)$; organic matter bound form $\left(\mathrm{HNO}_{3}+\mathrm{H}_{2} \mathrm{O}_{2}, \mathrm{H}_{2} \mathrm{O}_{2}, \mathrm{NH}_{4} \mathrm{OAc}\right)$; and residual form $\left(\mathrm{HF}+\mathrm{HNO}_{3}+\mathrm{H}_{2} \mathrm{O}_{2}\right)$. The supernatant liquid was separated from the solid phase by centrifugation at $1917 \mathrm{~g}$ for $20 \mathrm{~min}$ after each extraction step to determine the concentrations of $\mathrm{Cd}(\mathrm{mg} / \mathrm{kg}$ soil).

\section{Assessment methods of heavy metal pollution}

The single pollution index method (Hakanson 1980) was used to evaluate the risk of heavy metal pollution in soybean soil. The formula of the single pollution index method was as follows:

$I_{j}=C_{j} / C_{0}$

In the formula:

$I_{j}$ represents the single factor index of the pollution;

$C_{j}$ is the measured concentration of the pollution $(\mathrm{mg} / \mathrm{kg})$;

$C_{O}$ is the assessment standard of the pollution $(\mathrm{mg} / \mathrm{kg})$.

The contribution of $S$. indica in reducing Cd pollution was expressed by the decrease rate of Cd.

$R_{p}=\left(R_{s}-R_{c}\right) / R_{s}$

In the formula:

$R_{p}$ represents the decrease rate of $\mathrm{Cd}$;

$R_{S}$ is the concent of total Cd in soil inoculated with $S$. indica $(\mathrm{mg} / \mathrm{kg})$; 
$R_{C}$ is the content of total $\mathrm{Cd}$ in non inoculated $S$. indica soil $(\mathrm{mg} / \mathrm{kg})$.

\section{Statistical analysis}

The experimental data were statistically analyzed by Statistical Product and Service Solutions(SPSS) 22.0 software version. Two-way analysis of variance (ANOVA) was used to statistically analyze the significance of each treatment. The primary factors (S. indica and Cd levels) and their interactions were evaluated. Duncan's Multiple Range Test was used to compare the mean values of 0.05 and 0.01 probability levels. Data were expressed as the means of replicates \pm standard error (SE). Redundancy analysis (RDA) in CANOCO for Windows (version 5.0, Microcomputer power, Ithaca, NY, US; ter Braak et Šmilauer, 2019) was used to draw the relationships between variables.

\section{Result}

\section{Establishment of the symbiotic relationship between $\mathrm{S}$. indica and soybean}

S. indica can infect soybean roots, especially establish symbiotic relationships with mature root soybean (Fig. 1). The spore in soybean roots is a typical pear type. The results showed that with the CK, LH, MH, and $\mathrm{HH}$ treatments, the colonization rate of $S$. indica was $83.81 \%, 67.46 \%, 47.62 \%$ and $34.92 \%$ after inoculation (Table 1). The root colonization rate decreased significantly with the increase of $\mathrm{Cd}$ content in soil $(P<0.01)$. The infection rate of $S$. indica was the lowest under $\mathrm{HH}$ treatment (Table 1$)$. Though the colonization rate decreased, the $S$. indica was still functional. Still, the promotion effect of $S$. indica on soybean growth, soil enzyme activity and so on was limited at high Cd concentration (Table 1).

\section{Effects of S. indica on soybean growth and development}

If there is excessive $\mathrm{Cd}$ accumulated in the soil, the growth and development of plants will be incredibly restricted. However, these studies have suggested that inoculated $S$. indica can significantly alleviate this inhibition (Table 1). Compared with the control, $\mathrm{CK}, \mathrm{LH}, \mathrm{MH}$ and $\mathrm{HH}$ treatments with $S$. indica increased the plant height of soybean by $11.00 \%, 13.52 \%, 31.52 \%$ and $90.35 \%$. After treatment with $S$. indica, the dry weights of soybean under $\mathrm{Cd}$ concentration gradient were increased by $137.35 \% \otimes 116.60 \% \otimes 84.07 \%$ and $66.57 \%$, respectively. The maximum dry weight of soybean was $43.91 \mathrm{~g}$, obtained after treatment with CK and $S$. indica. The effect of the $S$. indica on the dry weight and plant height of soybean had different trends. Cd treatment and fungal treatment had significant main effects and interaction effects $(P<0.01)$ on root colonization and growth parameters of soybean (Table 1). 
Table 1

Effects of S. indica and Cd treatment on root colonization, plant height, and dry weight in soybean

\begin{tabular}{|c|c|c|c|c|}
\hline $\begin{array}{l}\text { Fungal } \\
\text { treatment }\end{array}$ & $\begin{array}{l}\text { Cd } \\
\text { treatment }\end{array}$ & $\begin{array}{l}\text { Root colonization } \\
(\%)\end{array}$ & $\begin{array}{l}\text { Shoot length } \\
\text { (cm) }\end{array}$ & $\begin{array}{l}\text { Dry weight } \\
\text { (g/plant) }\end{array}$ \\
\hline \multirow[t]{4}{*}{-S } & CK & $0 \pm 0 \mathrm{e}$ & $63.92 \pm 0.47 \mathrm{ab}$ & $18.50 \pm 0.44 c$ \\
\hline & LH & $0 \pm 0 \mathrm{e}$ & $56.50 \pm 0.50 \mathrm{ab}$ & $11.74 \pm 0.20 \mathrm{e}$ \\
\hline & $\mathrm{MH}$ & $0 \pm 0 \mathrm{e}$ & $46.00 \pm 0.70 \mathrm{c}$ & $9.23 \pm 0.75 f$ \\
\hline & $\mathrm{HH}$ & $0 \pm 0 \mathrm{e}$ & $30.47 \pm 1.75 d$ & $6.97 \pm 0.35 \mathrm{~g}$ \\
\hline \multirow[t]{4}{*}{$+S$} & CK & $83.81 \pm 0.33 a$ & $70.95 \pm 1.58 a$ & $43.91 \pm 1.49 a$ \\
\hline & LH & $67.46 \pm 0.36 b$ & $64.14 \pm 0.42 \mathrm{ab}$ & $25.43 \pm 1.03 b$ \\
\hline & $\mathrm{MH}$ & $47.62 \pm 0.41 c$ & $60.50 \pm 0.45 b$ & $16.99 \pm 0.72 \mathrm{~d}$ \\
\hline & $\mathrm{HH}$ & $34.92 \pm 0.14 \mathrm{~d}$ & $58.00 \pm 0.57 b$ & $11.61 \pm 0.66 \mathrm{e}$ \\
\hline \multicolumn{5}{|c|}{ Main effect } \\
\hline$-S$ & & $0 \pm 0 \mathrm{~b}$ & $52.16 \pm 1.37 b$ & $11.61 \pm 0.45 b$ \\
\hline \multirow[t]{6}{*}{$+S$} & & $58.45 \pm 0.95 a$ & $62.77 \pm 0.61 \mathrm{a}$ & $24.48 \pm 1.28 a$ \\
\hline & Main effec & & & \\
\hline & CK & $41.90 \pm 4.56 a$ & $66.73 \pm 0.51 a$ & $31.20 \pm 13.95 a$ \\
\hline & $\mathrm{LH}$ & $33.73 \pm 3.70 b$ & $61.85 \pm 0.51 a$ & $18.58 \pm 7.52 b$ \\
\hline & $\mathrm{MH}$ & $23.81 \pm 2.62 c$ & $55.67 \pm 0.88 b$ & $13.11 \pm 4.30 b$ \\
\hline & $\mathrm{HH}$ & $17.46 \pm 1.91 \mathrm{~d}$ & $48.82 \pm 1.46 \mathrm{c}$ & $9.29 \pm 2.59 b$ \\
\hline \multicolumn{5}{|l|}{ ANOVA } \\
\hline$S$ & & - & ** & $\star \star$ \\
\hline Cd & & -- & $\star \star$ & $\star \star$ \\
\hline $\mathrm{S} \times \mathrm{Cd}$ & & - & $\star \star$ & $\star \star$ \\
\hline
\end{tabular}

- S: non-inoculation (control), + S: S. indica. The value represents the mean \pm SE. The same letter in the same row of data in the table indicates significant no differences among treatments using Duncan's Multiple Range Test in the level of $\mathrm{P}<0.05$.

** $P<0.01$.

Effects of S. indica on photosynthesis of soybean

Understanding the photosynthetic response of plants is central to comprehending the physiological response. Table 2 showed the effects of $S$. indica and Cd on photosynthetic parameters of soybean. 
Compared with $\mathrm{CK}, \mathrm{LH}, \mathrm{MH}$, and $\mathrm{HH}$ treatments significantly reduced the net photosynthetic rate $(\mathrm{Pn})$, stomatal conductance $(\mathrm{Tr})$, intercellular $\mathrm{CO}_{2}$ concentration (Ci), and transpiration rate $(\mathrm{Gs})$ of soybean $(P$ $<0.05)$. Further, $\mathrm{Pn}, \mathrm{Tr}, \mathrm{Ci}$, and $\mathrm{Gs}$ were significantly different across $\mathrm{CK}, \mathrm{LH}, \mathrm{MH}$, and $\mathrm{HH}$ treatments $(P<$ 0.05). The application of $S$. indica increased $\mathrm{Pn}, \mathrm{Tr}, \mathrm{Gs}$, but reduced $\mathrm{Ci}$, and there was no significant difference in the intercellular $\mathrm{CO}_{2}$ concentration $(P<0.05)$. Compared with the uninoculated treatment, $S$. indica led to a maximum increase under $\mathrm{HH}$ in the $\mathrm{Pn}(72.18 \%), \operatorname{Tr}(80.73 \%)$, and $\mathrm{Gs}(119.05 \%)$, and maximum reduction under $\mathrm{CK}$ in $\mathrm{Ci}(12.93 \%)$. Data from Table 2 revealed that $\mathrm{Cd}$ treatment and fungal treatment had significant main effects and interaction effects $(P<0.01)$ on photosynthetic physiological parameters of soybean. 
Table 2

Effects of $S$. indica and Cd treatment on photosynthetic physiological indexes of soybean leaves

\begin{tabular}{|c|c|c|c|c|c|}
\hline $\begin{array}{l}\text { Fungal } \\
\text { treatment }\end{array}$ & $\begin{array}{l}\text { Cd } \\
\text { treatment }\end{array}$ & $\begin{array}{l}\text { Pn } \\
\text { (um/m²/s) }\end{array}$ & $\begin{array}{l}\operatorname{Tr} \\
\left(\mathrm{mmol} / \mathrm{m}^{2} / \mathrm{s}\right)\end{array}$ & Ci (ppm) & $\begin{array}{l}\text { Gs } \\
\left(\mathrm{mmol} / \mathrm{m}^{2} / \mathrm{s}\right)\end{array}$ \\
\hline \multirow[t]{4}{*}{$-S$} & CK & $\begin{array}{l}14.47 \pm 0.30 \\
c\end{array}$ & $3.79 \pm 0.29 b$ & $\begin{array}{l}366.40 \pm 25.48 \\
a\end{array}$ & $\begin{array}{l}257.80 \pm 24.30 \\
b c\end{array}$ \\
\hline & $\mathrm{LH}$ & $\begin{array}{l}12.45 \pm 0.96 \\
\text { de }\end{array}$ & $3.57 \pm 0.21 b$ & $339.67 \pm 7.37 b$ & $\begin{array}{l}237.00 \pm 5.57 \\
\mathrm{~cd}\end{array}$ \\
\hline & $\mathrm{MH}$ & $e^{11.30 \pm 1.02}$ & $2.30 \pm 0.14 c$ & $323.00 \pm 8.11 \mathrm{c}$ & $\begin{array}{l}211.75 \pm 13.84 \\
d\end{array}$ \\
\hline & $\mathrm{HH}$ & $6.65 \pm 0.33 f$ & $1.68 \pm 0.26 d$ & $\begin{array}{l}314.78 \pm 16.44 \\
\text { cd }\end{array}$ & $e^{143.00 \pm 29.26}$ \\
\hline \multirow[t]{4}{*}{$+S$} & CK & $\begin{array}{l}17.28 \pm 0.11 \\
a\end{array}$ & $4.43 \pm 0.30 \mathrm{a}$ & $\begin{array}{l}319.00 \pm 5.39 \\
\text { cd }\end{array}$ & $\begin{array}{l}322.67 \pm 15.47 \\
a\end{array}$ \\
\hline & $\mathrm{LH}$ & $\begin{array}{l}15.95 \pm 0.71 \\
b\end{array}$ & $3.77 \pm 0.36 b$ & $\begin{array}{l}318.44 \pm 4.90 \\
\mathrm{~cd}\end{array}$ & $\begin{array}{l}294.67 \pm 35.17 \\
a b\end{array}$ \\
\hline & $\mathrm{MH}$ & $\begin{array}{l}13.14 \pm 0.66 \\
d\end{array}$ & $3.68 \pm 0.12 b$ & $\begin{array}{l}317.88 \pm 11.41 \\
\text { cd }\end{array}$ & $\begin{array}{l}270.20 \pm 18.46 \\
\text { bc }\end{array}$ \\
\hline & $\mathrm{HH}$ & $\begin{array}{l}11.45 \pm 0.69 \\
e^{-10}\end{array}$ & $3.68 \pm 0.09 b$ & $303.89 \pm 7.94 \mathrm{~d}$ & $\begin{array}{l}258.44 \pm 17.75 \\
\text { bc }\end{array}$ \\
\hline \multicolumn{6}{|c|}{ Main effect } \\
\hline$-S$ & & $\begin{array}{l}11.86 \pm 2.79 \\
b\end{array}$ & $2.97 \pm 0.88 b$ & $\begin{array}{l}331.38 \pm \\
23.31 a\end{array}$ & $\begin{array}{l}202.53 \pm 53.81 \\
b\end{array}$ \\
\hline \multirow[t]{6}{*}{$+S$} & & $\begin{array}{l}14.28 \pm 2.34 \\
\mathrm{a}\end{array}$ & $3.83 \pm 0.35 a$ & $314.45 \pm 9.95 b$ & $\begin{array}{l}283.88 \pm 33.32 \\
\text { a }\end{array}$ \\
\hline & $\begin{array}{l}\text { Main } \\
\text { effect }\end{array}$ & & & & \\
\hline & CK & $\begin{array}{l}15.64 \pm 1.46 \\
a\end{array}$ & $4.02 \pm 0.43 a$ & $\begin{array}{l}327.21 \pm 14.70 \\
b\end{array}$ & $\begin{array}{l}293.18 \pm \\
38.776 a\end{array}$ \\
\hline & LH & $\begin{array}{l}13.95 \pm 1.98 \\
b\end{array}$ & $3.67 \pm 0.30 b$ & $320.72 \pm 6.91 \mathrm{a}$ & $\begin{array}{l}275.44 \pm \\
40.153 a\end{array}$ \\
\hline & $\mathrm{MH}$ & $\begin{array}{l}12.47 \pm 1.20 \\
C\end{array}$ & $2.99 \pm 0.73 c$ & $\begin{array}{l}338.75 \pm 29.12 \\
b\end{array}$ & $\begin{array}{l}244.22 \pm \\
34.514 \mathrm{~b}\end{array}$ \\
\hline & $\mathrm{HH}$ & $9.53 \pm 2.54 \mathrm{~d}$ & $3.01 \pm 1.00 \mathrm{c}$ & $\begin{array}{l}309.33 \pm 13.72 \\
c\end{array}$ & $\begin{array}{l}207.94 \pm \\
63.317 c\end{array}$ \\
\hline \multicolumn{6}{|l|}{ ANOVA } \\
\hline S & & $\star \star$ & $\star \star$ & $\star \star$ & $\star \star$ \\
\hline $\mathrm{Cd}$ & & $\star *$ & $\star \star$ & $\star \star$ & ** \\
\hline
\end{tabular}




\begin{tabular}{|llllll|}
\hline $\begin{array}{l}\text { Fungal } \\
\text { treatment }\end{array}$ & $\begin{array}{l}\mathrm{Cd} \\
\text { treatment }\end{array}$ & $\begin{array}{l}\mathrm{Pn} \\
\left(\mathrm{um} / \mathrm{m}^{2} / \mathrm{s}\right)\end{array}$ & $\begin{array}{l}\mathrm{Tr} \\
\left(\mathrm{mmol} / \mathrm{m}^{2} / \mathrm{s}\right)\end{array}$ & $\mathrm{Ci}(\mathrm{ppm})$ & $\begin{array}{l}\mathrm{Gs} \\
\left(\mathrm{mmol} / \mathrm{m}^{2} / \mathrm{s}\right)\end{array}$ \\
\hline $\mathrm{S} \times \mathrm{Cd}$ & & $* *$ & $* *$ & $* *$ & $* \star$ \\
\hline
\end{tabular}

- S: non-inoculation (control), + S: S. indica. The value represents the mean \pm SE. The same letter in the same row of data in the table indicates significant no differences among treatments using Duncan's Multiple Range Test in the level of $\mathrm{P}<0.05$.

** $P<0.01$.

\section{Effects of $S$. indica on the activities of soil enzymes under Cd stress}

Because soil enzymes participate in the catalytic process of various complex biochemical reactions, the soil enzyme activities can reflect the severity of soil pollution to a certain extent. Soil enzymes include urease, sucrase, catalase and so on. The activities of urease, sucrase, phosphatase and catalase in soil decreased as $\mathrm{Cd}$ concentrations rising during soybean harvest. The activities of soil urease $(53.48 \%)$ and phosphatase $(52.40 \%)$ were significantly between CK and the control $(P<0.05)$; the activities of phosphatase $(116.39 \%)$ and catalase $(4.17 \%)$ in LH were significantly higher than those of the control $(P$ $<0.05)$. Simultaneously, there was no significant difference in sucrase activities between $\mathrm{ML}, \mathrm{HH}$ and the control.

\section{Effects of $\mathrm{S}$. indica on $\mathrm{pH}$ and the decreasing rate of $\mathrm{Cd}$ in soil}

The contents of $\mathrm{Cd}$ and $\mathrm{pH}$ in the soil after harvest have shown in Fig. 3. The increase of $\mathrm{Cd}$ content decreased the soil $\mathrm{pH}$, and the soil $\mathrm{pH}$ of $S$. indica inoculated treatments were significantly higher than those of the control. The results were indicative that the $\mathrm{Cd}$ content in all $S$. indica treatments was lower than that of control, especially in the $\mathrm{MH}$ treatment. There was a significant difference between the inoculated $S$. indica treatment and the control $(P<0.01)$, inoculated $S$. indica decreased the Cd content in soil by $23.66 \%$.

\section{Effects of S. indica on soil Cd fraction}

Figure 3 showed the distribution of $\mathrm{Cd}$ in the soil tested by the Tessier sequential extraction. The result was reflected that soil $\mathrm{Cd}$ mainly combined with the exchangeable form, accounting for $40.78 \% \sim 54.86 \%$ of the total $\mathrm{Cd}$ in the rhizosphere soils. However, the exchangeable $\mathrm{Cd}$ in the rhizosphere soil was transformed into carbonate-bound and reducible iron and manganese forms in the $S$. indica treatments. Especially in the soil treatment of $\mathrm{MH}$, the decline rate of the control group was the largest (Fig. 4): exchangeable form (41.76\%), carbonate form (- 9.05\%), reducible iron and manganese form $(-11.48 \%)$, organic matter bound form (23.81\%) and residual form (4.00\%).

\section{Redundancy analysis of soybean growth index and environmental factors}


The relationship of soybean physiological indexes, soil enzyme activities and Cd chemical forms were analyzed through redundancy analysis (Fig. 5). The exchangeable form Cd accounted for $67.4 \%$, which can be considered as the main driver, the cumulative rate was $80.8 \%$, which could explain all variables. The growth indexes (dry weight, shoot height) of soybean and photosynthesis indexes (Gs, Pn, Tr) were in the second quadrants; The soil enzyme activities indexes (urease, phosphatase, sucrase and catalase) and $\mathrm{pH}$ were in the third quadrants. The chemical forms of $\mathrm{Cd}$ in soil were negatively correlated with growth, photosynthesis and soil enzymes and had a greater impact on $\mathrm{pH}$ and soil enzyme activities.

\section{Assessment of heavy metal pollution in soil}

The assessment of the contents of $\mathrm{Cd}$ in soybean soil revealed that the contents of $\mathrm{Cd}$ in the soil of inoculated and uninoculated $S$. indica treatments were higher compared to the limitation standards. Besides, the contents of $\mathrm{Cd}$ in inoculated $S$. indica treatments were significantly lower than those in control (Table 3). According to the limitation standard, the risk assessment of Cd pollution in soil indicated that: $\mathrm{Cd}$ content in $\mathrm{CK}, \mathrm{MH}$ and $\mathrm{HH}$ treatments reached extremely low, low and medium pollution levels, respectively; in LH treatment, inoculation of $S$. indica reached extremely low pollution level, and non-inoculation of $S$. indica reached low pollution level. According to the actual needs of the five alternatives, the risk of pollutant concentration assessment is divided into five levels according to the risk screening value of relevant standards (Ministry of ecological environment, China): extremely low (25 $\mathrm{mg} / \mathrm{kg}$ soil), very low (45 mg/kg soil), low medium (65 mg/kg soil), high ( $85 \mathrm{mg} / \mathrm{kg}$ soil), and extremely high (105 mg/kg soil).

Table 3

Heavy metal risk assessment results in soybean soil

\begin{tabular}{|lllll|}
\hline Fungal treatment & Cd treatment & $\begin{array}{l}\text { Measured value } \\
(\mathbf{m g} / \mathbf{k g ~ s o i l )}\end{array}$ & pollution index & Pollution level \\
\hline$-\mathrm{S}$ & $\mathrm{CK}$ & $0.31 \pm 0.09 \mathrm{e}$ & 6.58 & Extremely low \\
\hline & $\mathrm{LH}$ & $2.91 \pm 0.55 \mathrm{~d}$ & 25.33 & Low \\
\hline $\mathrm{MH}$ & $5.73 \pm 0.47 \mathrm{~b}$ & 44.09 & Low \\
\hline & $\mathrm{HH}$ & $7.08 \pm 0.70 \mathrm{a}$ & 60.21 & Medium \\
\hline $\mathrm{HS}$ & $\mathrm{CK}$ & $0.21 \pm 0.04 \mathrm{e}$ & 6.29 & Extremely low \\
\hline & $\mathrm{LH}$ & $2.28 \pm 0.52 \mathrm{~d}$ & 19.34 & Extremely low \\
\hline $\mathrm{MH}$ & $4.23 \pm 0.14 \mathrm{c}$ & 35.73 & Low \\
\hline $\mathrm{HH}$ & $5.05 \pm 0.77 \mathrm{~b}$ & 54.40 & Medium \\
\hline
\end{tabular}

\section{Discussion}

Effects of S. indica on soybean growth and development 
Cd has a extremely inhibitory effect on the growth and development of plants. $S$. indica can alleviate the stress of Cd on plants. In this research, the addition of exogenous $\mathrm{Cd}$ decreased the dry weight and plant height of soybean and the total dry weight $(6.97 \mathrm{~g})$ and the plant height $(30.47 \mathrm{~cm})$ were the lowest in the $\mathrm{HH}$ treatments. However, $\mathrm{S}$. indica treatments increased the dry weight and plant height of soybean and promoted the growth and development of Soybean (Table. 2), which are consistent with the findings of Wu et al. (2018). The study of Yun Ping et al. (2018) found that under salt alkali stress, the S. indica could regulate the transfer rate of $\mathrm{K}$ to the aboveground part, which was beneficial to the growth and development of plants. Thus we suspected that the increase of soybean biomass was due to the fact that $S$. indica promoted the absorption of nutrients and photosynthesis to improve the adaptability of host plants to Cd stress.

Photosynthesis plays a decisive role in the growth and development of plants. Therefore, plants will have withering and yellow leaves and other growth performance in the presence of Cd pollution in the soil. The inhibition of $\mathrm{Cd}$ on photosynthesis was the decrease of photosynthetic pigment and stomatal number. At present, the research on the effect of $S$. indica on plant photosynthesis mainly focused on non stomatal conductance factors such as chlorophyll synthesis, PSIl photochemistry and electron transport rate. However, $\mathrm{Pn}, \mathrm{Tr}, \mathrm{Ci}$ and $\mathrm{Gs}$ rate can also be used to estimate the photosynthetic physiological process of plants (Hui et al. 2015; Malkowski et al. 2020). There were many reports proved that $S$. indica can help plant resist saline alkali stress not only from promoting plant nutrient absorption, but also from improving stomatal conductance to grow and develop, which is good agreement with the results of ours (Yun et al. 2018; Liu et al. 2020).

Our result expounded that compared with the control, treatments with exogenous $\mathrm{Cd}$ significantly decreased Pn, Tr, Gs, and Ci (Table 2). This change may be caused by the decrease of stomatal conductance and the obstruction of $\mathrm{CO}_{2}$ entering leaves when soybeans were stressed by $\mathrm{Cd}$, which led the decrease of $\mathrm{Pn}$, which was the stomatal limitation of photosynthesis (Liu et al. 2020). The Ci value of the treatment with inoculation of $S$. indica decreased may be because $\mathrm{CO}_{2}$ was the raw material of photosynthesis, the less $\mathrm{CO}_{2}$ between cells, the more carbon dioxide consumed in photosynthesis, the greater Pn, which was opposite to Tsai et al. (2020). In the study of rice, S. indica can reduce the toxic effect of $\mathrm{Cd}$ by stomatal closure and oxidative stress reduction. The main reason for this result may be that the host selected was different (Klichowska et al. 2019). There was research also indicated that the decrease of photosynthesis under $\mathrm{Cd}$ stress was related to the decrease of carboxylase and ribose 1, 5diphosphate carboxylase activities (Song et al. 2019). However, the application of S. indica enhanced Gs, $\mathrm{Pn}$, Tr of soybean (Table 2). S. indica can effectively improve the stability of $\mathrm{Cd}$ and reduce the inhibition of Cd on photosynthesis.

\section{Effects of $S$. indica on the activities of soil enzymes under Cd stress}

The soil enzyme is an important biocatalyst in soil, which reveals ecosystem perturbations and plays an irreplaceable role in the detoxification process of pollutants. It can also facilitate the biogeochemical cycle of nutrients, maintain soil structure, and produce the necessary compounds for microorganisms 
and plants (Gelsomino et al. 2006; Topac et al. 2009; Hu et al. 2014). Many studies demonstrated that Cd had adverse effects on soil enzyme activities (Ali et al. 2020). On the one hand, pollutants inhibit enzyme activity by silencing catalytic active groups that led to protein conformational denaturation. On the other hand, pollutants may compete with the enzyme's substrate, thus hindering the enzyme from functioning (Kizilkaya and Bayrakli 2005). Among the different soil enzymes, soil urease, sucrase and phosphatase are often used to evaluate the nutrient absorption of plants and organic matter transformation, and catalase was often used to evaluate the detoxification ability of soil ecosystem.

In this study, we also observed that $\mathrm{Cd}$ contamination had adverse effects on soil enzyme activities. The activities of urease, sucrase and catalase in the $\mathrm{LH}, \mathrm{MH}$ and $\mathrm{HH}$ treatments were significantly lower than those of control. The decrease of soil enzyme activities was due to the increase of heavy metal content and decreased pH value (Fig. 5). A result showed that the soil enzyme activities decreased with the increase of heavy metal concentration, and Cd inhibited the activities of urease and catalase (Wang et al. 2020). On the one hand, the reason for $S$. indica to played a role might be that $S$. indica promoted the growth of soybean (Table 2), stimulated the secretion of plant root metabolites, and directly enhanced soil enzyme activity. Similar to endophytic plant growth promoting bacteria and arbuscular mycorrhizal fungi, S. indica might improve the activity of urease, sucrase and phosphatase in soil to absorb sufficient $\mathrm{C} / \mathrm{N}$ / P from soil, and significantly increased soybean biomass (Table 2), which can make the root system absorb and accumulate $\mathrm{Cd}$; on the other hand, S. indica stimulated soil microorganisms, which increased the biomass and activity of microorganisms, and indirectly increased the activity of soil enzymes. The effect of microorganism on soil enzyme activity is more complex. We observed that the soil enzyme activity decreased with the increase of $\mathrm{Cd}$ concentration, and plants inoculation with $S$. indica in the root, which increased soil enzyme activities, in turn. The phosphatase and catalase activities in soybean soil, which inoculated $S$. indica were significantly increased under $\mathrm{MH}$. It is similar to the conclusion of Xiao et al. (2021), which in highly Cd-polluted soils, Trifolium repens with mycorrhizal inoculation and straw treatment, phosphatase activity and catalase activity were promoted, and reduced Cd toxicity via a dilution effect.

Heavy metal ecotoxicity and soil enzyme activity are closely related to soil physical and chemical properties (Heidari et al. 2020), especially can be significantly affected by soil pH value. RDA results demonstrated a positive correlation between soil enzyme activity and soil pH value. That is, the decrease of soil $\mathrm{pH}$ value could represent the adverse effect of $\mathrm{Cd}$ on soil enzyme activity. The change of soil pH value in $\mathrm{S}$. indica treatment was the result of multiple factors. The increase of $\mathrm{Cd}$ content led to more organic acids secreted by plant roots, decreased soil pH and increased metal availability, making plants absorb more heavy metals (Zeng et al. 2020). Notably, in HH treatments, the soil pH was enhanced from 7.60 to 7.68 with $S$. indica, indicating that $S$. indica may reduce the content of soil organic acid to effectively inhibit of soil acidification process. (Fig. 5d). The research of Yang et al. (2020) found that the citric and malic acids in rhizosphere soil of inoculating AMF were significantly higher than the control under $\mathrm{Cd}$ stress. Besides, the decrease of exchangeable $\mathrm{Cd}$ form may be due to the significant reduction of organic acid release from soybean roots by $S$. indica (Fig. 4). 
The toxicity of heavy metals was mainly related to the exchangeable form, which was highly mobile and easy to enter into plants. On the contrary, carbonate form and reducible iron and manganese form were relatively stable components, which were not easy to enter the plants (Liu et al. 2014). Figure 3 illustrated that the $\mathrm{Cd}$ component has been gradually transformed into a more stable component from an exchangeable form and effectively immobilized in the soil. Also, the changes of chemical forms of $\mathrm{Cd}$ indicated that the application of $S$. indica could significantly reduce the bioavailability of $\mathrm{Cd}$.

Moreover, the form of $\mathrm{Cd}$ in soil and the proportion of various forms are the key factors to determine its impact on the environment and the surrounding ecosystem (Lee et al. 2015). Previous studies also reported that the exchangeable fraction of $\mathrm{Cd}$ accounted for the highest proportion of $\mathrm{Cd}$ concentration in soil (Nemati et al. 2011). Generally, soil pH, organic matter and redox conditions all affected the forms of heavy metals in soil, but $\mathrm{pH}$ is the most important factor. It was found that the decrease of $\mathrm{pH}$ value by only 0.2 unit will lead to the increase of exchangeable Cd by 3-5 times (Zhu et al. 2016; Meng et al. 2020). The results showed that the application of $S$. indica to soils could contribute to higher $\mathrm{pH}$, which increased the contents of carbonate bound and residual form $\mathrm{Cd}$ to immobilize $\mathrm{Cd}$ in the soil. According to the single pollution index method, under the treatment of $10 \mathrm{mg} / \mathrm{kg} \mathrm{Cd}$, inoculation of $S$. indica could effectively reduce the level of $\mathrm{Cd}$ pollution, indicating that the use of $S$. indica could reduce the risk of $\mathrm{Cd}$ pollution in the soil.

These results were confrmed by RDA analysis. The chemical forms of $\mathrm{Cd}$ in soil were negatively correlated with the content of DW, SH and photosynthetic parameters of soybean, indicating that the accumulation of $\mathrm{Cd}$ in soil greatly inhibited the physiological indexes of soybean. Indeed, the photosynthetic parameters of soybean was positively correlated with urease, sucrase, phosphatase and catalase in soil. In this study, $S$. indica caused a positive effect on the growth and development of soybean to attenuate the toxic effects of $\mathrm{Cd}$ on soybean, and ultimately enhanced soil enzyme activities of soybean soil to reduce the accumulation of $\mathrm{Cd}$.

\section{Conclusions}

Pot experiments were conducted to examine $S$. indica on soil enzyme activities, physiological characteristics of soybean and the potential risks of heavy metal pollution to soybean. According to the investigation results, the following conclusions can be drawn:

(1) Cd contamination in the soil caused physiological dysfunctions of plants. Cd reduced root colonization and growth and also affected the photosynthesis of soybean plants. Inoculation of $S$. indica mitigated the negative impact of $\mathrm{Cd}$ by enhancing growth and improvement in $\mathrm{Pn}, \mathrm{Tr}$, Gs.

(2)The increase of $\mathrm{Cd}$ concentration lowered soil $\mathrm{pH}$, which not only inhibited the activities of soil enzymes, but also increased the risks of heavy metals pollution. Besides, $S$. indica can reduce $C d$ toxicity by enhancing soil pH, promote soil enzyme activities, and reduce exchangeable $\mathrm{Cd}$ in soil. 
(3) In our study, the Cd content in the soil inoculated with $S$. indica significantly decreased. According to the single pollution index method analysis, $S$. indica minimized the risk of soil heavy metal pollution in $\mathrm{LH}$ treatment, which indicated that these $S$. indica treatments could improve soil health.

We suggest $S$. indica can be used as a microbial fertilizer and heavy metal remediation agent in $\mathrm{Cd}$ contaminated soils to realize sustainable agriculture.

\section{Abbreviations}

Cd, Cadmium, S. indica, Serendipita indica, $\mathrm{Pn}$, net photosynthetic rate, $\mathrm{Tr}$, stomatal conductance, $\mathrm{Ci}$, intercellular $\mathrm{CO}_{2}$ concentration, $\mathrm{Gs}$, transpiration rate.

\section{Declarations}

Author contribution

Song F. Q.: Funding acquisition, Conceptualization, Proofreading, Methodology, Writing - review \& editing. Wang, X.H.: Investigation, Writing - review, Performed experiments, Writing - original draft, Data analysis \& editing. Fan X.X.: Proofreading, Writing - review \& editing. Wang W.D.: Investigation and data analysis. All authors read and approved the manuscript.

Ethics approval The ethical consent was approved by the Research Ethics Committee of the Life Sciences College at Heilongjiang University (Harbin, China)

Consent to participate: All the patients provided their informed consent for participation to the study.

Consent for publication: All the authors have read and approved the manuscript and accorded the consent for publication.

Competing interests: The authors declare no competing interests.

\section{Fundings}

The authors are grateful for the financial support of the Natural Science Foundation of Heilongjiang Province (TD2019C002), National Natural Science Foundation of China (31971527).

Data availability

Supporting data set will be made available upon reasonable request.

\section{References}

1. Akum FN, Jens S, Dagmar B, Jafargholi I, Karl-Heinz K (2015) The piriformospora indica effector piin_08944 promotes the mutualistic sebacinalean symbiosis. Frontiers in Plant Science 6(906). 
2. Alga Z, Urs L, Ulrich G, Gregor L, Stefanie P, Dagmar B, Philip W, Birgit S, Carolin G, Magdalena B, Claude M, Karl-Heinz K (2011) Endophytic Life Strategies Decoded by Genome and Transcriptome Analyses of the Mutualistic Root Symbiont Piriformospora indica. PLoS Pathogens 7(10),

3. Ali A, Shaheen SM, Guo D, Li YM, Xiao R, Wahid F, Azeem M, Sohail K, Zhang T, Rinklebe J, Zhang ZQ (2020) Apricot shell- and apple tree-derived biochar affect the fractionation and bioavailability of $\mathrm{Zn}$ and $\mathrm{Cd}$ as well as the microbial activity in smelter contaminated soil. Environmental Pollution 264.

4. Ge Y, Wang Q, Wang L, Liu W, Christie P (2017) Response of soil enzymes and microbial communities to root extracts of the alien alternanthera philoxeroides. Archives of Agronomy and Soil Science 64(5).

5. Gelsomino A, Badalucco L, Landi L, Cacco G (2006) Soil carbon, nitrogen and phosphorus dynamics as affected by solarization alone or combined with organic amendment. Plant and Soil 279(1-2), 307-325.

6. Hakanson L (1980). An ecology risk index foraquaticpollution control: a sedimentologicalapproach. Water Research 14(8), 975-1001.

7. Heidari E, Mohammadi K, Pasari B, Rokhzadi A, Sohrabi Y (2020) Combining the phosphate solubilizing microorganisms with biochar types in order to improve safflower yield and soil enzyme activity. Soil science and plant nutrition 66(2), 255-267.

8. Hilbert M, Nostadt R, Zuccaro A (2013) Exogenous auxin affects the oxidative burst in barley roots colonized by piriformospora indica. Plant Signaling \& Behavior 8(4), 520-34.

9. Hill TW, Käfer E (2001) Improved protocols for aspergillus minimal medium: trace element and minimal medium salt stock solutions. Fungal Genetics Reports 48(1), 20-21.

10. Hu XF, Jiang Y, Shu Y, Hu X, Liu L, Luo F (2014) Effects of mining wastewater discharges on heavy metal pollution and soil enzyme activity of the paddy fields. Journal of Geochemical Exploration 147, 139-150.

11. Hui FQ, Liu J, Gao QK, Lou BG (2015) Piriformospora indica confers cadmium tolerance in Nicotiana tabacum. Journal of environmental sciences 184-191.

12. Klichowska E, Nobis M, Piszczek P (2019) Soil properties rather than topography, climatic conditions, and vegetation type shape AMF-feathergrass relationship in semi-natural European grasslands. Applied Soil Ecology 144: 22-30.

13. Kizilkaya R, Bayrakli B (2005) Effects of N-enriched sewage sludge on soil enzyme activities. Applied Soil Ecology 30(3), 192-202.

14. Lee PK, Choi BY, Kang MJ (2015) Assessment of mobility and bio-availability of heavy metals in dry depositions of asian dust and implications for environmental risk. Chemosphere 119. 1411-1421.

15. Li H, Chen XW, Wu L, Luo N, Wong MH (2020) Effects of arbuscular mycorrhizal fungi on redox homeostasis of rice under Cd stress. Plant and Soil 455(1-2).

16. Liu H, Yang L, Li N, Zhou C, Han X (2020) Cadmium toxicity reduction in rice (Oryza sativa I.) through iron addition during primary reaction of photosynthesis. Ecotoxicology and Environmental Safety $200,110746$. 
17. Li DX, Li CD, Jing C, Liu LT, Sun HC, Zhang YJ (2014) Effects of cadmium (Cd) on seedling growth traits and photosynthesis parameters in cotton (gossypium hirsutum I.). Plant Omics 7(4), 284-290.

18. Liu HJ, Yang L, Li N, Zhou CJ, Feng H, Yang JF, Han X (2020) Cadmium toxicity reduction in rice (Oryza sativa L.) through iron addition during primary reaction of photosynthesis. Ecotoxicology and Environmental Safety 200.

19. Meng J, Cui Z, Zhang H, Zhang J, Shan S (2020) Combined effects of arbuscular mycorrhizae fungus and composted pig manure on the growth of ryegrass and uptake of $\mathrm{Cd}$ and $\mathrm{Zn}$ in the soil from an e-waste recycling site. Environmental Science and Pollution Research (15), 1-9.

20. Makowski E, Sitko K, Szopiński M, Gieroń A, Pogrzeba M, Kalaji HM, Zielenik-Rusinowska P (2020) Hormesis in plants: the role of oxidative stress, auxins and photosynthesis in corn treated with $\mathrm{Cd}$ or $\mathrm{Pb}$. International Journal of Molecular Sciences 21(6).

21. Ministry of Ecology and Environment. Soil environmental quality risk control standard for soil contamination of development land: GB 36600-2018[R/OL].

22. Ministry of Ecology and Environment. Standard of soil quality assess $₫$ ment for exhibition sites: $\mathrm{HJ}$ 350-2007[R/OL].

23. Nemati K, Bakar NKA, Abas MRB, Sobhanzadeh E, Low KH (2011) Comparison of unmodified and modified BCR sequential extraction schemes for the fractionation of heavy metals in shrimp aquaculture sludge from selangor, malaysia. Environmental Monitoring and Assessment 176(1-4), 313-320.

24. Padash A, Shahabivand S, Behtash F, Aghaee A (2016) A practicable method for zinc enrichment in lettuce leaves by the endophyte fungus piriformospora indica under increasing zinc supply. Scientia Horticulturae 367-372.

25. Phillips JM (1970) Improved procedures for clearing roots and staining parasitic and vesiculararbuscular mycorrhizal fungi for rapid assessment of infection. Transactions of the British Mycological Society 55.

26. Ruchika B, Yinyin H, Sebhat G, Brian M, Heather B, Ram P, Ajit V, Bushley KE (2018) Transcriptional responses of soybean roots to colonization with the root endophytic fungus piriformospora indica reveals altered phenylpropanoid and secondary metabolism. Scientific Reports 8(1), 149.

27. Satarug S, Nishijo M, Ujjin P, Vanavanitkun Y, Baker JR, Moore MR (2004) Effects of chronic exposure to low-level cadmium on renal tubular function and CYP2A6-mediated coumarin metabolism in healthy human subjects. Toxicology Letters 148(3), 187-197.

28. Sebastian A, Prasad MNV (2019) Photosynthetic light reactions in oryza sativa I. under Cd stress: influence of iron, calcium, and zinc supplements. The EuroBiotech Journal 3(4), 175-181.

29. Shahabivand S, Parvaneh A, Aliloo AA (2017) Root endophytic fungus piriformospora indica affected growth, cadmium partitioning and chlorophyll fluorescence of sunflower under cadmium toxicity. Ecotoxicology and Environmental Safety. 145, 496-502.

30. Shayan M, Jagriti S, Kushwaha AS, Kapil M, Jai S, Nidhi A, Saxena PN, Ram N, Roy SK, K Manoj K (2017). Endophytic fungi piriformospora indica mediated protection of host from arsenic toxicity. 
Frontiers in Microbiology 8.

31. Song X, Yue X, Chen W, Jiang H, Li X, (2019) Detection of cadmium risk to the photosynthetic performance of hybrid pennisetum. Frontiers in Plant Science 10.

32. Trasar-Cepeda C, Cami? F, Leirós MC, Gil-Sotres F (1999) An improved method to measure catalase activity in soils 31(3):0-485.

33. Tsai HJ, Shao KH, Chan MT (2020) Piriformospora indica symbiosis improves water stress tolerance of rice through regulating stomata behavior and ROS scavenging systems. Plant Signaling \& Behavior 15(2).

34. Topac FO, Dindar E, Ucaroglu S, Baskaya HS (2009) Effect of a sulfonated azo dye and sulfanilic acid on nitrogen transformation processes in soil. Journal of Hazardous Materials 170(2-3), 10061013.

35. Tessier A, Campbell P, Bisson M (1979) Sequential extraction procedure for the speciation of particulate trace metals. Analytical Chemistry 51, 844-851.

36. Valente AJM (2019) Assessment of heavy metal pollution from anthropogenic activities and remediation strategies: a review. Journal of Environmental Management 246.

37. Vahabi K, Dorcheh SK, Monajembashi S, Westermann M, Reichelt M, Falkenberg D, Hemmerich P, Sherameti I, Oelmüller R (2016) Stress promotes arabidopsis - piriformospora indica interaction. Plant signaling \& behavior 11(5), 12.

38. Vieira MA, Ribeiro AS, Lúcia Felicidade Dias, Adilson José Curtius (2005) Determination of Cd, Hg, Pb and $\mathrm{Se}$ in sediments slurries by isotopic dilution calibration ICP-MS after chemical vapor generation using an on-line system or retention in an electrothermal vaporizer treated with iridium. Spectrochimica Acta Part B: Atomic Spectroscopy 60(5), 643-652.

39. Wang L, Zou R, Li YC, Tong ZH, You M, Huo WM, Chi KY, Fan HL (2020) Effect of wheat-solanum nigrum I. intercropping on $\mathrm{Cd}$ accumulation by plants and soil bacterial community under cd contaminated soil - sciencedirect. Ecotoxicology and Environmental Safety 206.

40. Wu MY, Wei Q, Xu L, Li HZ, Oelmüller R, Zhang WY (2018) Piriformospora indica enhances phosphorus absorption by stimulating acid phosphatase activities and organic acid accumulation in Brassica napus. Plant and Soil 432(1-2), 333-344.

41. Xian PQ, Cai ZD, Cheng YB, Lin RB, Lian TX, Ma QB, Nian H (2020) Wild Soybean Oxalyl-CoA Synthetase Degrades Oxalate and Affects the Tolerance to Cadmium and Aluminum Stresses. International journal of molecular sciences 21(22).

42. Xiao Y, Zhao Z, Chen L, Li Y (2021) Arbuscular mycorrhizal fungi mitigate the negative effects of straw incorporation on trifolium repens in highly Cd-polluted soils. Applied Soil Ecology 157, 103736.

43. Yang HF, Yan M, Yao J, Wang YB, Liu DY(2007) Impact of Cu and Zn pollution on rape growth and soil enzyme activity. Chin. J. Applied Ecology 18, 1484-1490.

44. Yang X, Qin J, Li J, Lai Z, Li H (2020) Upland rice intercropping with solanum nigrum inoculated with arbuscular mycorrhizal fungi reduces grain $\mathrm{Cd}$ while promoting phytoremediation of $\mathrm{Cd}$ contaminated soil. Journal of Hazardous Materials. 
45. Yun P, Xu L, Wang SS, Lana S, Sergey S, Zhang WY (2018) Piriformospora indica improves salinity stress tolerance in Zea mays $\mathrm{L}$. plants by regulating $\mathrm{Na}^{+}$and $\mathrm{K}^{+}$loading in root and allocating $\mathrm{K}^{+}$in shoot. Plant Growth Regulation 86(2), 323-331.

46. Zeng F, Ali S, Zhang H, Ouyang Y, Qiu B, Wu F, Zhang G (2011) The influence of pH and organic matter content in paddy soil on heavy metal availability and their uptake by rice plants. Environmental Pollution 159(1), 84-91.

47. Zhi Y, Sun T, Zhou Q, Leng X (2020) Screening of safe soybean cultivars for cadmium contaminated fields. Scientific Reports 10(1).

48. Zhu H, Chen C, Xu C, Zhu Q, Huang D (2016) Effects of soil acidification and liming on the phytoavailability of cadmium in paddy soils of central subtropical china. Environmental Pollution 219, 99-106.

\section{Figures}

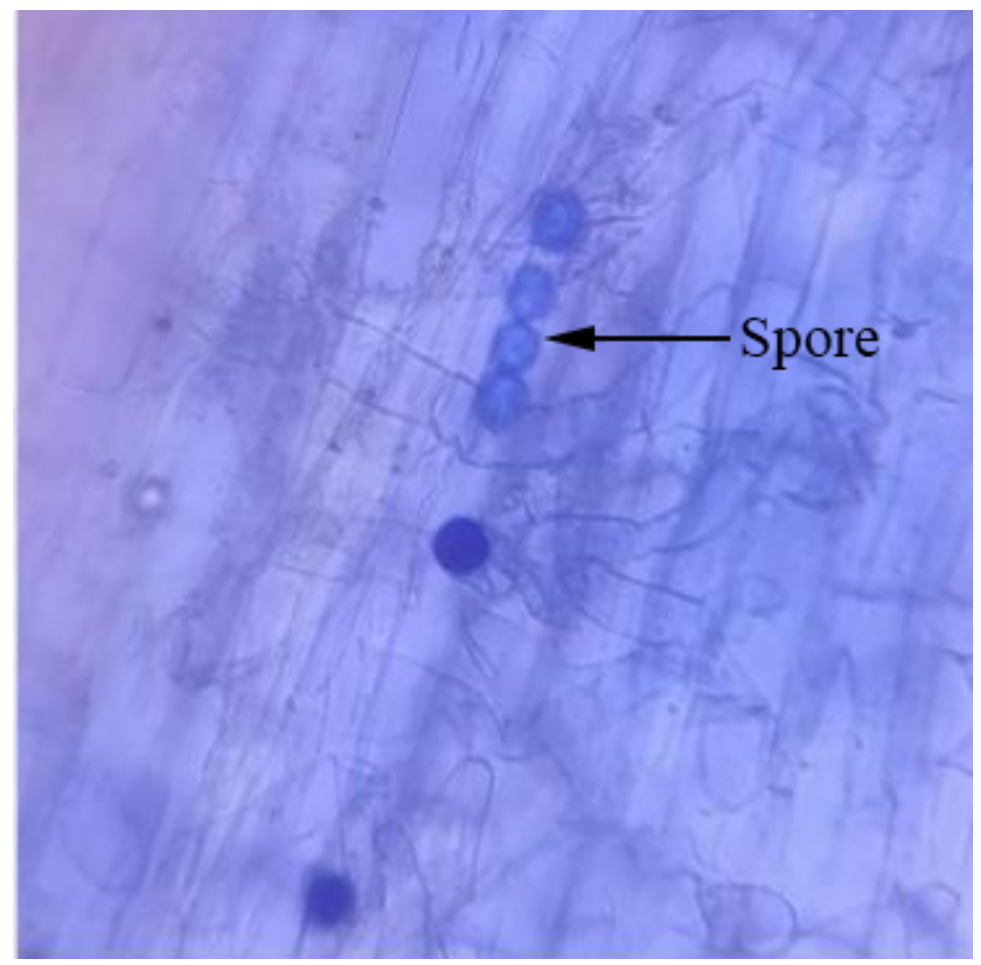

\section{Figure 1}

Infection of S. indica on soybean observed under the microscope. Hyphae, and chlamydospores of S. indica under the light microscope, magnification 200x. Trypan blue $(0.001 \mathrm{mg} / \mathrm{ml})$ method. 

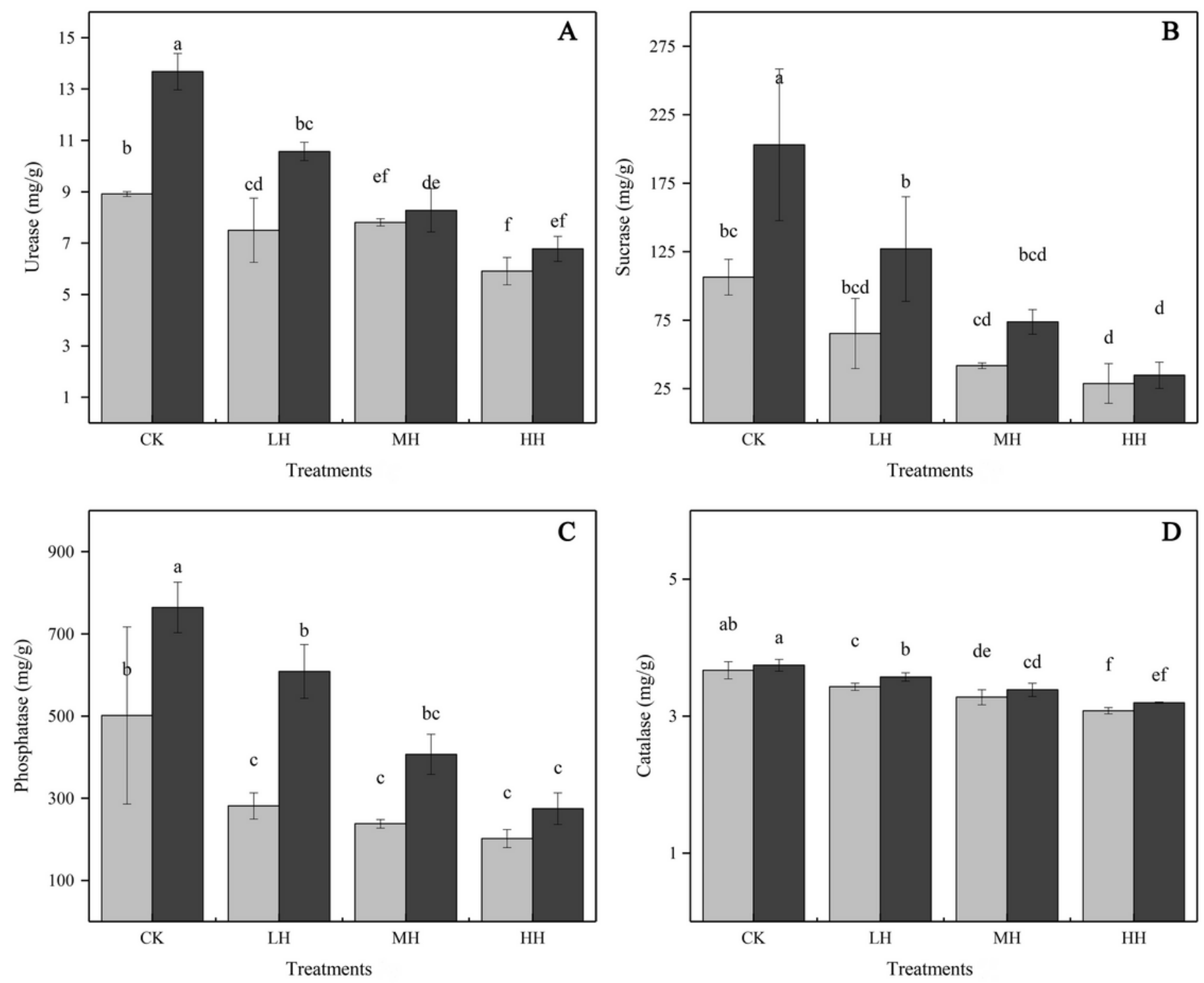

$-\mathrm{S} \square+\mathrm{S}$

\section{Figure 2}

Effects of S. indica on soil urease (A), sucrase (B), phosphatase (C) and catalase (D) activities as well as $\mathrm{Cd}$ residue in $\mathrm{Cd}$ contaminated soil 

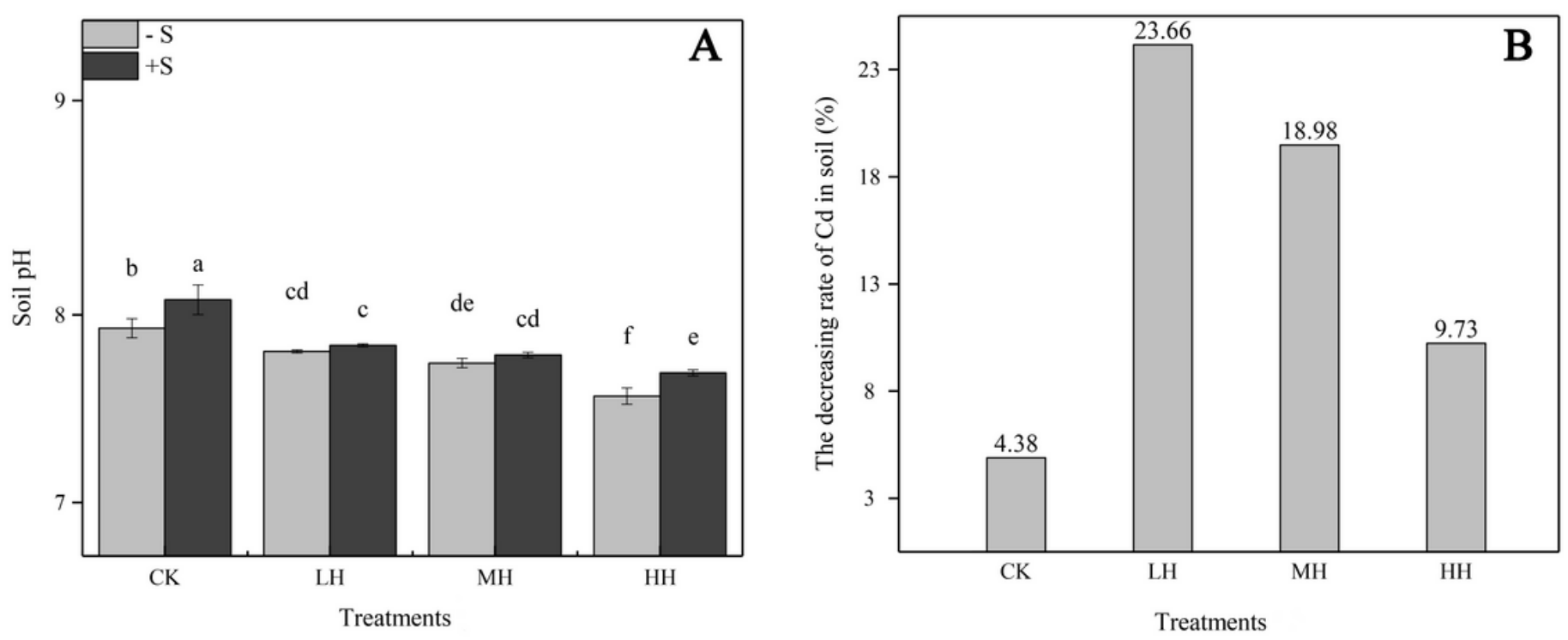

Figure 3

Effects of S. indica on soil pH and the decreasing rate of Cd in soil, (A) Effects of $\mathrm{S}$. indica on soil pH under $\mathrm{Cd}$ pollution, (B) Contribution of $\mathrm{S}$. indica reduce $\mathrm{Cd}$ pollution. 


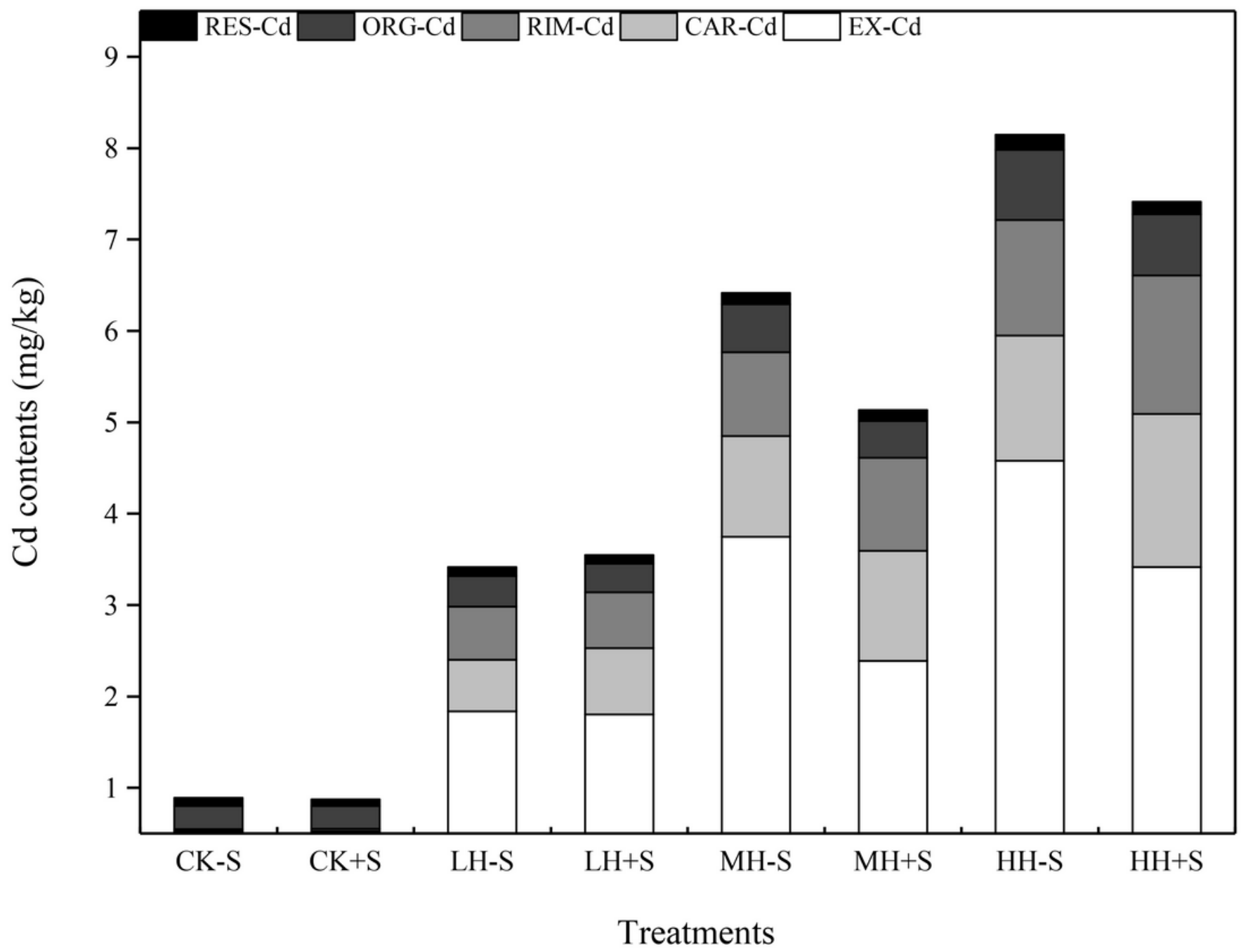

Figure 4

Fractionation of $\mathrm{Cd}$ in the rhizosphere soil of soybean at the harvest time (EX-Cd: exchangeable form, CAR-Cd: carbonate form, RIM-Cd: reducible iron and manganese form, ORG-Cd: organic matter bound form, RES-Cd: residual form.) 


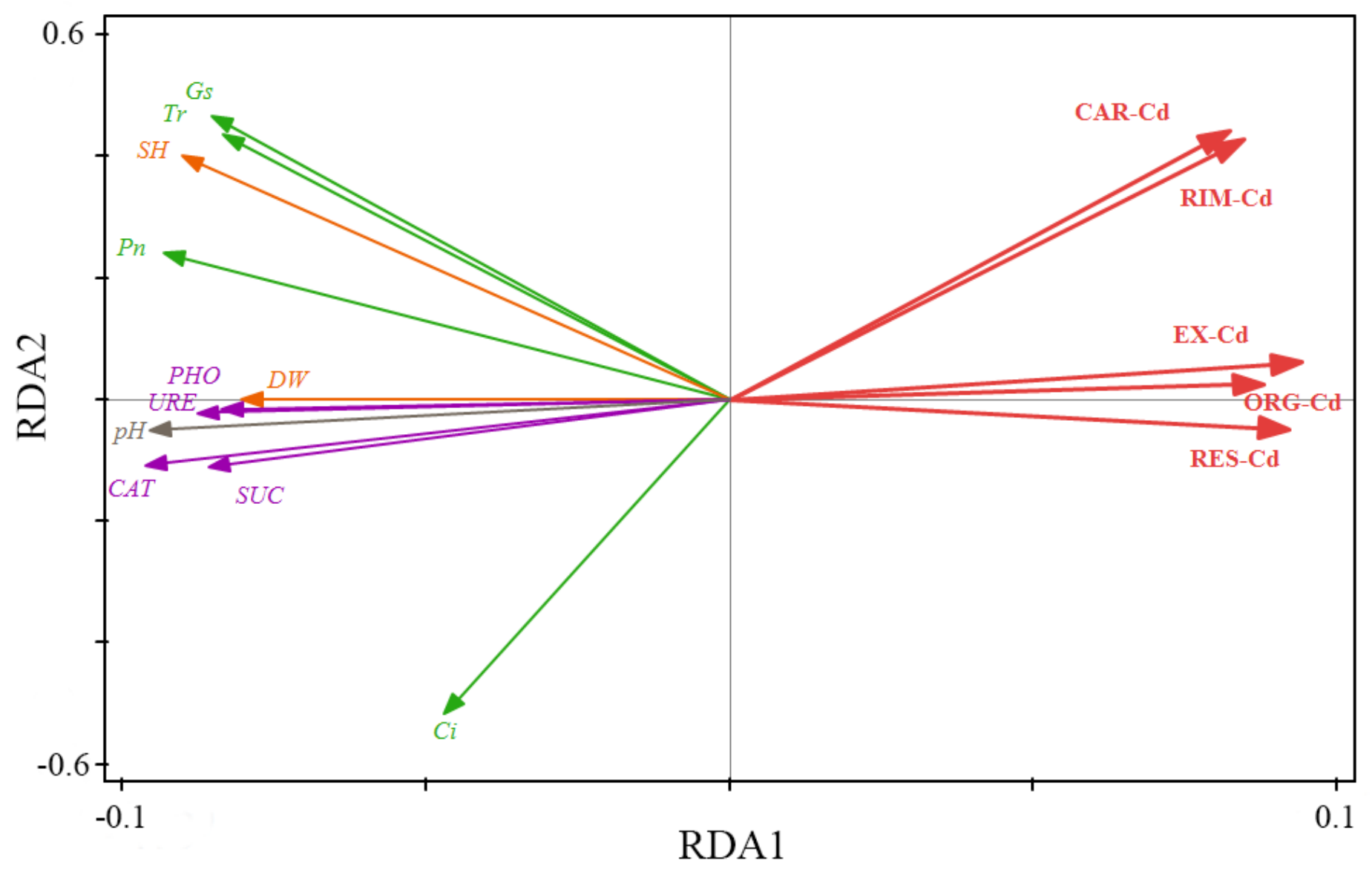

Figure 5

Redundancy analysis of soybean growth and soil health. EX-Cd: exchangeable form, CAR-Cd: carbonate form, RIM-Cd: reducible iron and manganese form, ORG-Cd: organic matter bound form, RES-Cd: residual form, represents, DW: dry weight, SH: shoot height, URE: urease, PHO: phosphatase, SUC: sucrase, CAT: catalase, Tr: transpiration ratio, Gs: stomatal conductance, Pn: net photosynthesis rate, Ci: intercellular CO2 concentration.

\section{Supplementary Files}

This is a list of supplementary files associated with this preprint. Click to download.

- GraphicalAbstract.jpg 